\title{
STUDY OF COLONIC CELL PROLIFERATION INDUCED BY CHRONIC TOXICTTY OF ORLISTAT AND THE POSSIBLE PROTECTIVE EFFECT OF GINSENG IN EXPERIMENTAL ANIMALS
}

\author{
BY \\ Eman I. Hasan, Jaklin F. Zaher, Ghada A. Eshak \\ and Nashwa F. El-Tahawy* \\ Deparments of Forensic Medicine \& Toxicology and Histology* \\ Faculty of Medicine - Minia University, Egypt
}

\begin{abstract}
Orlistat is a widely used anti-obesity agent available as a non-prescription medication in many devel. oped countries. Its long term use may result in an increasing frequency of chronic toxicity. This work was designed to clarify the effect of Orlistat on the colonic cell proliferation and the formation of colonic aberrant crypt foci ( $A C F)$ and to investigate the possible ameliorating effect of Ginseng in experimental animals. Eighty adult male albino rats were used in this work; group I (control group) received a standard diet. Group II (Ginseng group) fed on diet containing 1\% red Ginseng. Group III (high fat diet group, HFD) fed on 10\% corn-oil enriched diet. Group IV (Orlistat group) received oral Orlistal (125 $\mathrm{mg}$ I kg / day), group V (Orlistat + HFD group). Group VI (HFD + Ginseng group). Group VII (Orlistat + Ginseng group) and lastly group VIII (Orlistat + HFD + Ginseng group). Afier 16 weeks, animals were sacrificed and their colons were immunostained using proliferating cell nuclear antigen (PCNA) as a marker of cell proliferation which is the biomarker of increased susceptibility to gastrointestinal cancer. Results showed that Orlistat and /or HFD resulted in increased immunolabelling for PCNA causing a statistically significant increase in PCNA-labelling Index (PCNA-LI) when compared with the control groups. Ginseng when combined with Orlistat or HFD or Orlistat + HFD caused a significant decrease of both the immunolabelling and PCNA-L1. Consequently, it has been proposed to clarify the long-term impact of Orlistat treatment for physicians working in this field and for the public by the drug brochure. Also, Ginseng should be given with Orlistat as a protective agent to ameliorate its proliferative effect on the colonic mucosa.
\end{abstract}

\section{INTRODUCTION}

Obesity is an ever-expanding global heaith problem, which contributes significantly to individual poor health and societal burden of disease. A number of con- comitant pathological processes and diseases are associated with obesity including coronary heart disease, hypertension, stroke, non-insulin dependent diabetes mellitus and certain forms of cancer. Besides changes in diet, behavior and physi- 
cal activities, obesity may be treated by surgery or pharmacological therapy. Gastrointestinal symptoms have been commonly seen in $75 \%$ of the patients who had clinical treatment for obesity (Peter \& Keith, 2004).

Orlistat is an anti-obesity drug used for long term management of obesity and its long-term safety is still to be determined. It decreases absorption of dietary fat by inhibiting gastric and pancreatic lipases through covalent modification of the enzymes (PDR, 2006).

It is also a potent inhibitor of fatty acid synthase (FAS) functions through inhibition of the thioesterase activity of FAS (Dowling et al., 2009). The inactivated enzymes become unable to hydrolyze dietary fat preventing its digestion and absorption (Caner et al., 2005). Thus, the fecal fat excretion is significantly increased with Orlistat (Nishioko et al., 2003).

Many laboratory animal studies suggest that fat has a direct action on the colonocytes causing increase its proliferation and upward shift in the proliferation zone of the colonic crypts. This promotes the appearance of the aberrant crypt foci (ACF) -that are considered to be the earliest putative preneoplastic lesion- enhancing colorectal cancer. Many hypotheses tried to explain such mechanism. The most widely accepted hypothesis is that dietary fat leads to increase the cytotoxic fecal bile acids that induces damage to the colonic mucosal epithelial cells with subsequent compensatory hyperproliferation (Ahnen et al., 2007).

PCNA also called cyclin, was discovered through an autoantibody in the serum of a patient with systemic lupus erythematosus that specifically reacted with the nuclei of proliferating cells. It was identified as an auxiliary protein of 36 $\mathrm{kDa}$ of DNA polymerase-delta (Yamashita et al., 1994). PCNA has been found to be a useful marker in immunocytochemical studies of cell proliferation because its expression correlates with the proliferative state of the cell (Martínez-Lara et al., 1996). It is also a nuclear protein involved in DNA-synthesis and repair, and associated with $\mathrm{S}$ phase and DNA replication of the cell cycle (Motiwale et al., 2005).

Thus, the purpose of the present study was to verify the effect of chronic administration of Orlistat on the colonic cell proliferation and the formation of colonic aberrant crypt foci (ACF) determined by proliferating cell nuclear antigen (PCNA) immunohistochemistry and to investigate the role of Ginseng as a protective agent.

\section{MATERIALS \& METHODS}

This work was carried out in the Department of Forensic Medicine and Toxi- 
cology, Faculty of Medicine - Minia University. All aspects of animal care and treatment were carried out according to the local guide line of the Ethical Committee of Faculty of Medicine, Minia University.

Eighty adult male albino rats were used in this work with average weight of $(180 \pm 20 \mathrm{gm})$. They were housed in standard polypropylene cages (five rats/cage) and maintained under a controlled room temperature with 12:12 $\mathrm{h}$ light and dark cycle. All rats were provided with commercially available normal rat diet and water ad libitum for two weeks before experiment for acclimatization.

Rats were divided into eight experimental groups (10 rats each):

Group I (control group): Rats fed only on ordinary rat diet.

Group II (Ginseng group): Rats fed on diet enriched with $1 \%$ red Ginseng (Pharco Pharmaceuticals) according to Fukushima et al., (2001).

Group III (High fat diet group) "H.F.D": Rats fed on 10\% cornoil enriched diet.

Group IV (Orlistat group): Rats received Orlistat "Eva Pharmaceutical Company" at a dose of $125 \mathrm{mg} / \mathrm{kg} /$ day according to EMEA, 2005. This dose is equivalent to $1 / 40$ of LD50
(Hoffmann La-Roche Inc, 2008).

Group V (Orlistat + HFD group): Rats received Orlistat at a dose of $125 \mathrm{mg} / \mathrm{kg} /$ day and $10 \%$ corn oil enriched diet daily.

Group VI (HFD + Ginseng group): Rats fed on diet containing 10\% corn oil and $1 \%$ red Ginseng.

Group VII (Orlistat + Ginseng group): Rats received Orlistat at a dose of $125 \mathrm{mg} / \mathrm{kg} /$ day orally and $1 \%$ red Ginseng enriched diet.

Group VIII (Orlistat + HFD + Ginseng group): Rats fed on diet containing $10 \%$ corn oil $+1 \%$ red Ginseng and received Orlistat at a dose of $125 \mathrm{mg} / \mathrm{kg} /$ day orally.

Animals were observed regularly. After 16 weeks; rats were sacrificed by decapitation under light halothane anesthesia. The large bowel was rapidly removed and longitudinally opened as closely as possible to the mesenteric border throughout its full extension. The distal colon was fixed in $10 \%$ buffered formalin, segmented into small pieces and processed for different histological examinations.

The colonic segments were washed in tap water and then stained with $40 \mathrm{~mL}$ of $0.2 \%$ methylene blue for 3-5 minutes. Subsequently, the excess stain was washed off with tap water for five minutes. For observation by light microscopy, the mucosa 
was cut into small pieces and placed under two glass slides $(1 \times 1 \mathrm{~cm})$ and examined with mucosal surface up according to Piva-Demarzo \& Garcia (2004).

Other segments were cut as a ring of the organ and were also embedded in paraffin and the paraffin blocks were cut serially maintaining the original transverse orientation so as to provide ring-shaped sections ( $7 \mu \mathrm{m}$ sections) used for Hematoxylin and Eosin staining and immunohistochemistry staining.

\section{Immunohistochemical staining and} morphometry:

Seven-micrometre sections were used for immunohistochemical staining for the Proliferating cell nuclear antigen (PCNA). In brief, sections were deparaffinized, hydrated then washed in $0.1 \mathrm{M}$ phosphate buffer saline (PBS). Endogenous peroxidases were quenched by treatment with $\mathrm{H}_{2} \mathrm{O}_{2}$ in methanol (Peroxidase blocking solution) followed by washing in tris buffer saline (TBS). Non-specific binding of IgG was blocked using normal goat serum, diluted in $0.1 \%$ bovine serum albumin with TBS for 30 minutes. The sections were incubated with the diluted primary antibodies; mouse monoclonal PCNA, for 30 minutes at room temperature. Sections then were washed 3 times each for $5 \mathrm{~min}$ utes in buffer and incubated for further 30 minutes with biotinylated goat anti-rabbit secondary antibodies diluted 1:1000, followed by washing. Following further 30 minutes incubation with Vectastain $A B C$ kits (Avidin, Biotinylated horse radish peroxidase Complex) and washing for 10 minutes, the substrate -diaminobenzidine tetra hydrochloride (DAB) in distilled water- was added for 5-10 min. The slides were lightly counterstained by hematoxylin. This substrate gives brown color of the proliferating nucleus.

PCNA immunolabeled cells were counted in 10 adjacent non overlapping fields of the cross tissue sections of each rat. The total number of cells of the same colonic glands was also assessed by counting their all nuclei in the same fields. The ratio between numbers of PCNAimmunolabeled cells to the total number of cells was calculated in each experimental group (Kubben et al., 1994).

To estimate the colonic cell proliferation in the colon of all animals, PCNA immunolabeled cell nuclei were counted in 100 colonic crypts. The PCNA-labelling index (PCNA-LI) was expressed as a ratio of positively stained nuclei to a total number of counted nuclei per 100 crypts in each experimental group (Kubben et al., 1994).

\section{Data handling and statistics:}

The mean number $(\mathrm{M})$ and standard 
deviation $( \pm S D)$ were determined in each group. Statistical analysis of the data was performed by using SPSS version 15.0 (SPSS Inc., Chicago, IL, USA) for windows. Student's t-test was performed and $p \leq 0.05$ was considered statistically significant.

\section{RESULTS}

All rats survived to the final sacrifice. Diarrhea was observed in rats during Orlistat administration. Intestinal lumens of the animals fed on Orlistat were observed to be empty after they were sacrificed. No macroscopic changes were observed in the colons. The histopathological examination of methylene blue stained mucosa showed that rats of all groups lacked any ACF in the colon (Fig.1).

\section{Immunohistochemical study:}

Light microscopic examination of colons of the control and Ginseng-treated groups (I \& II) revealed normal structural components of the colon which displayed normal mucosa consisting of surface lining, intestinal glands, lamina propria and muscularis mucosa. The mucosal lining showed slight immunostaining for PCNA (proliferative marker) which mainly was localized to the lower part of the glands (sites of stem cells in large intestine) (Fig. 2A). Groups III, IV, VIII showed increases in the immunolabelling for PCNA (Fig. 2B). Group V showed marked increase in the immunolabelling for PCNA (Fig. 2C). Groups VI, VII showed obvious decreases in immunolabeled cells (Fig. 2D).

Higher magnifications of sections of control groups (I \& II) displayed few detectable immunolabelling for PCNA (Fig. 3A). Groups III, IV, VIII showed increases in the immunolabelling for PCNA (Fig. $3 B$ ). In group $V$, there was a marked increase in the immunolabelling for PCNA. It also showed areas of stratifications. The immunolabeling was mainly confined to cellular nuclei of the colonic glands but some stromal cells showed immunopositivity for PCNA (Fig. 3C). Groups VI, VII showed obvious decreases in immunolabeled cells (Fig. 3D).

\section{Results of PCNA-labelling Index (PCNA-LI):}

An Orlistat and / or high fat diet (HFD) caused an increase in the PCNA-LI positive cells when compared to the control groups. Orlistat and / or HFD with Ginseng showed a decrease in PCNA-LI but still higher in comparison with the control groups (Table 1). All groups except the Ginseng group showed significant $(\mathrm{P}=0.0001)$ increase in PCNA-LI in comparison with the control group (Table 2). Rats fed on Ginseng with Orlistat and / or HFD showed significant $(P=0.0001)$ increase in PCNA-LI in comparison with Ginseng group (Table 3). 
In the presence or absence of Ginseng, the association of high fat diet (HFD) and Orlistat produced a cumulative effect on the increase of the PCNA-LI when compared to Orlistat alone or HFD alone. Feeding of the Orlistat-treated rats with Ginseng decreased the PCNA-LI significantly. The PCNA-LI was significantly suppressed within the animals fed high fat diet with red Ginseng. Group VIII which were supplied with Orlistat + HFD + Ginseng showed no difference in comparison with Orlistat alone or HFD alone, but showed significant decrease in comparison with Orlistat + HFD group and significant increase when compared with Orlistat + Ginseng and HFD + Ginseng groups (Table 4).

\section{DISCUSSION}

A lot of studies have been done with Orlistat in humans (Joyce, 1998). Clinical and experimental studies have reported positive effects of Orlistat on lipid profile and glucose levels (Sjostrom et al., 1998), on gallbladder stones formation (FDA, 2007), on drug-induced bullous leukocytoclastic vasculitis (Lazic et al., 2011) and on liver injury (Umemura et al., 2006) and (FDA Drug Safety Communication, 2010).

Many controversies had been established about Orlistat and cancer association. While some reported positive association with cancer breast (Lee-Ping, 1997) and cancer colon (Takayama et al., 1998) and (Radtke \& Clevers, 2005), others stated that breast cancer occurrence was likely to be a chance finding (EMEA, 2005). Orlistat was found by others (Dowling et al., 2009), (Kridel et al., 2004) to inhibit the proliferation of gastric tumor cells in mice and prostatic cancer cells cultured in serum free media. So this study was designed to rule out the effect of Orlistat on rat's colonic mucosa to verify any positive or negative association with hyperproliferating activity.

According to the results of the present study; Diarrhea was observed in rats during the 6 weeks of Orlistat administration which is compatible with results of Caner et al., (2005) and Li \& Cheung (2009). EMEA, (2005) attributed all GIT symptoms due to the changes in vitamins $\mathrm{D}, \mathrm{E}$, and $\beta$-carotene levels.

Results showed that HFD or Orlistat or even both together lacked aberrant crypt foci in rat's colons, these findings met with results of Garcia et al. (2006). But, The FDA pharmacology review of Roche's high fat / low calcium study noted that there was a treatment-related increase in the number of colonic aberrant crypt foci in rats with Orlistat (David, 1997).

Increased cell proliferation has been proposed to be a biomarker of increased susceptibility to gastrointestinal cancer. 
PCNA can be used as a proliferating index of a broader spectrum of cells than other parameters (Yamashita et al., 1994).

PCNA-LI positive cells were observed in high number in rats fed on Orlistat. An important explanation for these findings is what observed by Melia et al. (1996) who reported that Orlistat significantly reduces the absorption of vitamin $\mathrm{E}$. As vitamin $\mathrm{E}$ supplementation ( $90 \mathrm{mg} / \mathrm{kg}$ diet) caused a significant decrease in the number of aberrant crypt foci (Narayan et al., 1995) and (Victor \& Ronald, 2006) and vitamin E enriched-diets was found to have a protective effect on oxidative DNA damage (Morin et al., 2008). So, Vitamin E deficiency combined with free radicals generation was highly involved in the proliferation of the aberrant crypt foci. Furthermore, Orlistat may inhibit the absorption of vitamin $D$, which plays an important role in the colonic cancer prevention (Murillo et al., 2010).

A recent explanation of these results that showed increasing in PCNA-LI positive cells in rats fed on HFD that was designed by Bernstein and his coworkers (2011) that a high fat diet is associated with increased risk of cancer colon. HFD may have its carcinogenic potential mediated through the action of bile acids which act as tumor promoters, and that some dietary anti-oxidants may ameliorate this carcinogenicity.
The higher number of the preneoplastic PCNA-LI positive cells observed in rats fed on Orlistat and HFD was due to the linear-accumulative effect on tumor cells (Dowling et al., 2009). The exact mechanism is not fully known; while David (1997) noted fatty changes and fatty infiltrations of rat tissues "probably attributed to inhibition of cellular lipases" due to absorption of the drug, Thornton \& MacDonald (Thornton \& MacDonald, 1997) proposed that the dietary fat induces changes in the cell membrane lipid composition and proliferation in the colon and these changes may be related to the development of tumors. The free radicals formation may be involved in these changes, since a diet rich in fat increases the in vitro formation of a reactive oxygen species (ROS) in feces (Erhardt et al., 1997). ROS was found by lain et al. (2007) to cause colonic mucosal damage.

The authors thought that the possibility of colon cancer was raised in the view of increased lipid content in the colonic fecal matter and current epidemiological data linking human colon cancer and increased fat intake. Contrary to the present results; EMEA, (2005) stated that the available epidemiological evidence showed that the relationship between fat intake and colonic cancer is doubtful. Increased energy intake was incriminated as the main risk factor whereas fat intake could be a confounding factor. 
To best of the knowledge; this is the first time to try Ginseng to prevent the possible premalignant pathological changes induced by Orlistat and / or high fat diet. Ginseng is believed to have been used in medicinal preparations for about $2000 \mathrm{yr}$ in Oriental countries. Several pharmacological activities have been reported for Ginseng (Fukushima et al., 2001). Preventive effects of Ginseng against cancer development have been observed by many authors (Saw et al., 2010), (Choi et al., 2011), (Hao et al., 2011) and (Toh et al., 2011). The present results proved that Ginseng significantly decreased the PCNA-LI positive cells in both Orlistat and / or high fat diet-treated rats. Saponins were considered to be the major active components of red Ginseng. Saponins have been reported to have antimutagenic activity, inhibiting tumour angiogenesis and metastasis as well as reducing growth of several tumour cell lines ( $\mathrm{Li}$ et al., 2000).

\section{CONCLUSION \& RECOMMENDATION}

1- Orlistat and / or HFD increased the proliferating marker PCNA in the colon. So, people with vulnerability to cancer colon must avoid Orlistat intake as well as HFD. This is an important alarm to change bad habits in feeding and avoid unnecessary medications.

2- Broadcasting this effect must be done for both physicians and people.

3- Ginseng caused a marked decrease of the high PCNA-LI induced by chronic Orlistat administration and / or HFD. Thus, Ginseng must be added to Orlistat as a protective agent to ameliorate its hyperproliferating effect. 
Table (1): Mean values for PCNA-LI positive cells among studied groups.

\begin{tabular}{|c|c|}
\hline Groups & $M \pm S D$ \\
\hline I & $M \pm S D$ \\
\hline II & $7.60 \pm 2.37$ \\
\hline III & $8.30 \pm 2.21$ \\
\hline IV & $23.60 \pm 2.22$ \\
\hline V & $22.700 \pm 2.31$ \\
\hline VI & $32.800 \pm 2.29$ \\
\hline VII & $15.2 \pm 1.93$ \\
\hline VIU & $15.1 \pm 2.13$ \\
\hline
\end{tabular}

Group I: control group

Group III: High Fat Diet group (HFD)

Group V: Orlistat + HFD group

Group VII: Orlistat + Ginseng group
Group II: Ginseng group

Group IV: Orlistat group

Group VI: HFD + Ginseng group

Group VIII: Odlistat + HFD + Ginseng group

Table (2): Statistical comparison for PCNA-LI positive cells between control and other studied groups.

\begin{tabular}{|c|c|c|c|}
\hline Groups & Mean & $\boldsymbol{t}$ & $\boldsymbol{P}$ \\
\hline I vs II & 0.700 & 0.657 & 0.527 \\
\hline I vs III & 16.00 & 17.411 & $0.0001^{* *}$ \\
\hline I vs IV & 15.10 & 15.733 & $0.0001^{* *}$ \\
\hline I vs V & 25.200 & 27.139 & $0.0001^{* *}$ \\
\hline I vs VI & 7.60 & 8.143 & $0.0001^{* *}$ \\
\hline I vs VII & 7.500 & 6.277 & $0.0001^{* *}$ \\
\hline I vs VIII & 14.700 & 17.99 & $0.0001^{* *}$ \\
\hline
\end{tabular}

Group I: control group

Group III: High Fat Diet group (HFD)

Group V: Orlistat + HFD group

Group VII: Orlistat + Ginseng group

$P \leq 0.05$ : significant

vs: versus
Group II: Ginseng group

Group IV: Orlistat group

Group VI: HFD + Ginseng group

Group VIHI: Orlistat + HFD + Ginseng group

$\mathrm{P}<0.001$ : highly significant ${ }^{\star \star}$ 
Table (3): Effect of Ginseng treatment in PCNA-LI positive cells in the studied groups.

\begin{tabular}{|c|c|c|c|}
\hline Groups & Mean & $T$ & $P$ \\
\hline II vs VI & 6.90 & 6.866 & $0.0001^{* *}$ \\
\hline II vs Vח & 6.80 & 8.500 & $0.0001^{* *}$ \\
\hline II vs VII & 14.00 & 19.170 & $0.0001^{* *}$ \\
\hline
\end{tabular}

Group II: Ginseng group

Group VII: Orlistat + Ginseng group $P \leq 0.05$ : significant vs: versus
Group VI: HFD + Ginseng group

Group VIrI: Orlistat $+\mathrm{HFD}+$ Ginseng group $P<0.001$ : highly significant**

Table (4): Comparison of PCNA-LI positive cells among different treated groups.

\begin{tabular}{|l|c|c|c|}
\hline Group & Mean & $\boldsymbol{t}$ & $\boldsymbol{P}$ \\
\hline III vs V & 9.20 & 9.783 & $0.0001^{* *}$ \\
\hline III vs VI & 8.4 & 18.578 & $0.0001^{* *}$ \\
\hline III vs VII & 1.300 & 1.414 & 0.191 \\
\hline IV vs V & 10.10 & 8.787 & $0.001^{*}$ \\
\hline IV vs VII & 7.60 & 9.601 & $0.0001^{* *}$ \\
\hline IV vs VIII & 0.40 & 0.524 & 0.613 \\
\hline V vs VII & 10.50 & 14.932 & $0.0001^{* *}$ \\
\hline VI vs VIII & 7.10 & 7.398 & $0.0001^{* *}$ \\
\hline VII vs VIII & 7.20 & 7.137 & $0.0001^{* *}$ \\
\hline
\end{tabular}

Group III: High Fat Diet group (HFD)

Group V: Orlistat + HFD group

Group VII: Orlistat + Ginseng group

$P \leq 0.05$ : sigrificant

vs: versus
Group IV: Orlistat group

Group VI: HFD + Ginseng group

Group VIII: Orlistat + HFD + Ginseng group

$P<0.001$ : highly significant ${ }^{* *}$ 


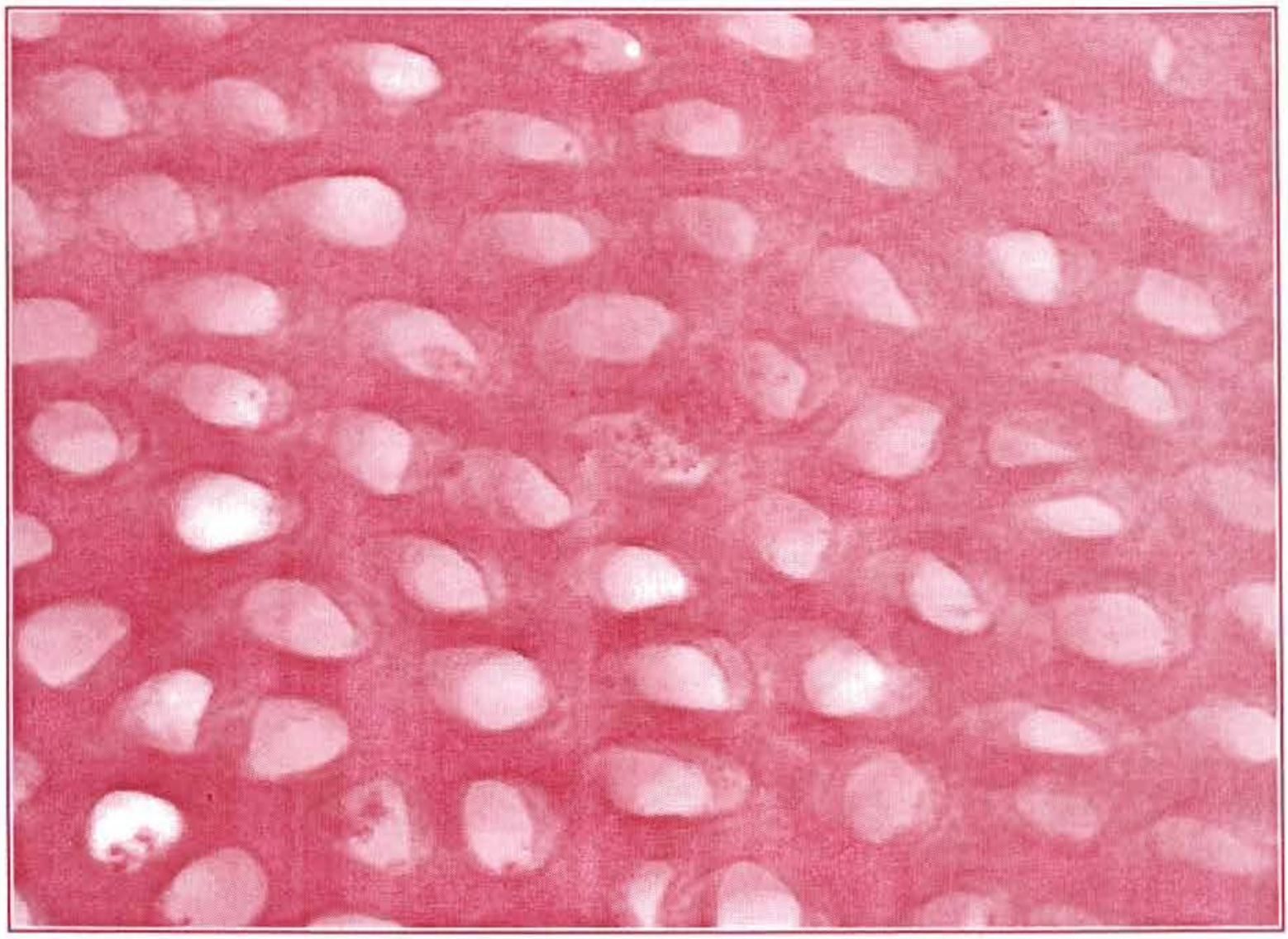

Figure (1): Photomicrograph of control rat colon showing normal appearance of colonic mucosa lacking criteria of aberrant crypt foci (ACF). The surface openings of the glands appeared of equal sizes, not elevated, and patent with no slit-like openings (Mcthytene blue, X100). 

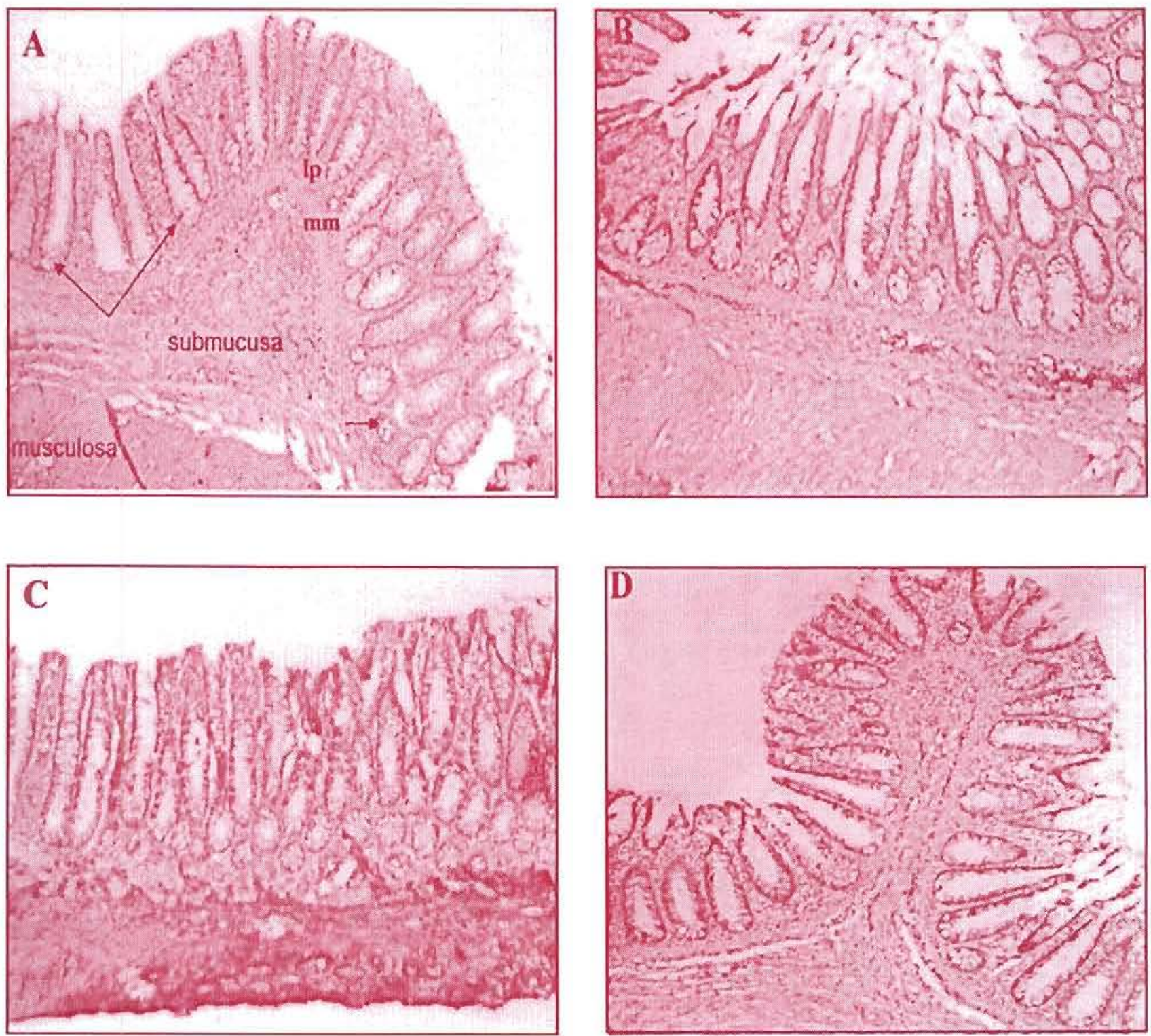

Figure (2): Photomicrographs of rat colons labeled for PCNA, showing: A) control groups with normal mucosa which traversed by intestinal crypts (glands), lamina propria (lp), and muscularis mucosa $(\mathrm{mm})$. The mucosal lining showing slight immunolabeling which mainly localized to the lower part of the glands (arrows). B) Groups III, IV, VIII showed increased immunolabeling of the glands. C) Group V showed extensive immunolabeling. D) Groups VI \& VII showed decreased immunolabeling (Immunohistochemistry, X100). 

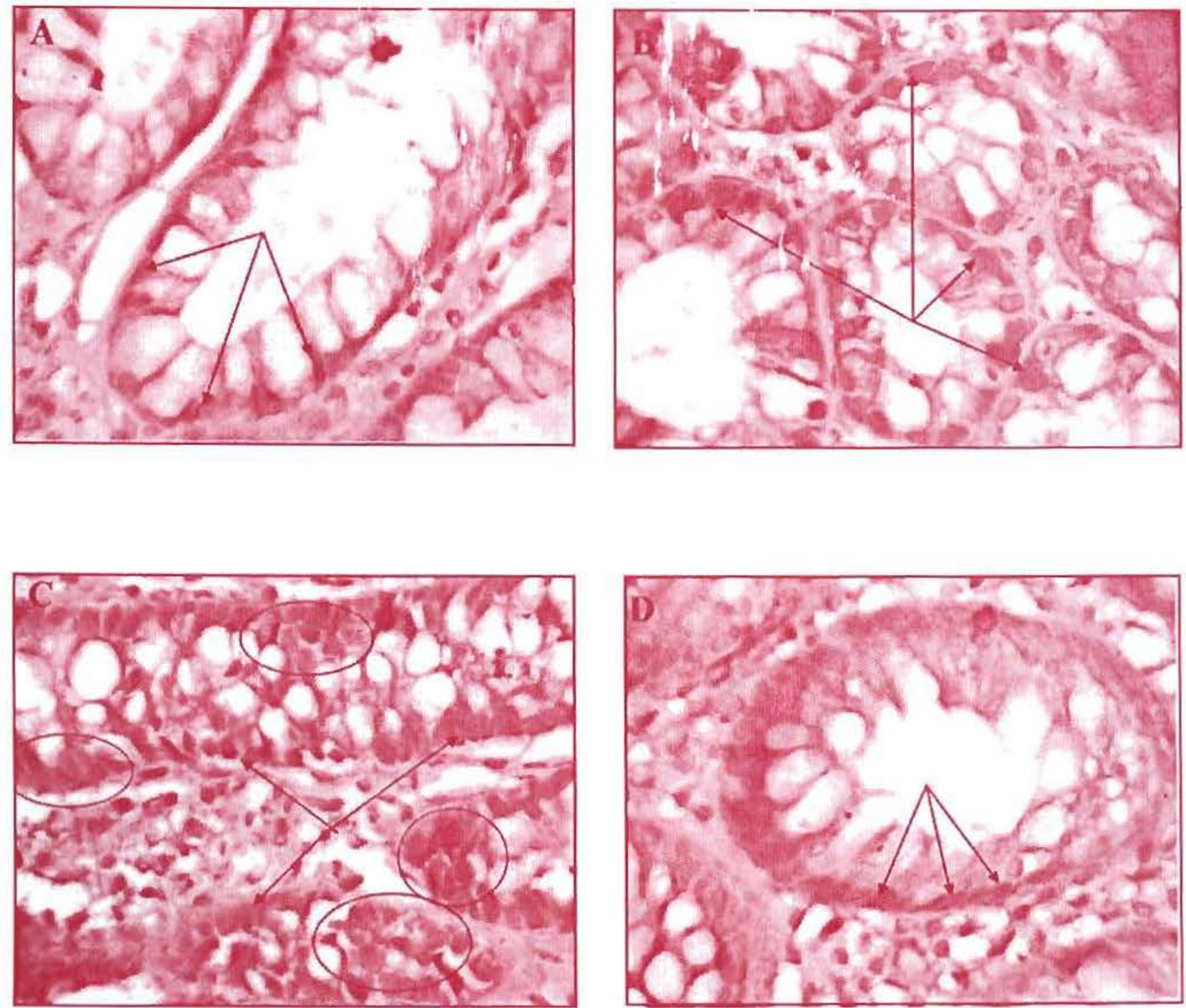

Figure (3): Photomicrographs of cross sections of rat colons labeled for PCNA, showing: A) control groups with few immunolabeled cells (arrows). B) Groups III, IV, VII showed increased immunolabeling of cells "arrows". C) Group V showed extensive immunolabeling of cells "arrows". Notice areas of stratifications "circles". D) Groups VI, VII showed decreased immunolabeled cells "arrows" (Immunohistochemistry, $\times 1000$ ). 


\section{REFERRENCES}

Ahnen, D. J.; Guercoilini, R.; Hauptman, J.; Blotner, S.; Woods, C. J. and Wargovich, M. J. (2007) : "Effect of Orlistat on fecal fat, fecal biliary acids and colonic cell proliferation in obese subjects". Clinical Gastroenterology and Hepatology, 5: 1291-1299.

Bernstein, C.; Holubec, H.; Bhattacharyya, A. K.; Nguyen, H.; Payne, C. M.; Zaitlin, B. and Bernstein, H. (2011) : "Carcinogenicity of deoxycholate, a secondary bile acid", Arch. Toxicol., Jan. 26 [Epub ahead of print].

Caner, M.; Dogruman, H.; Taskin, E.; Kandill, A. and Demirci, C. (2005) : "Effects of Orlistat and its relationship with nitric oxide in the small intestinal mucosa". Chinese Journal of Physiology, 48(4): 217-222.

Choi, Y. J.; Choi, H.; Cho, C. H. and Park, J. W. (2011) : "Red ginseng deregulates hypoxia-induced genes by dissociating the HIF-1 dimer". J. Nat. Med., 18 [Epub ahead of print].

David, H. (1997) : "FDA Pharmacology Review of Orlistat". Available at http://www.fda.gov/cder/foi /nda/99/ 020766a_xenical phrmr_. P5.pdf. Now available at: http://web, archive.org/web /20070225211225/http://www.fda.gov/ cder/foi/nda/99/020766a_xenical_ phrmr_P5.pdf. Last visited March 2, 2009.

Dowling, S.; Cox, J. and Cenedella, R. (2009) : "Inhibition of fatty acid synthase by Orlistat accelerates gastric tumor cell apoptosis in culture and increases survival rates in gastric tumor bearing mice in vivo". Lipids, 44: 489-498.

EMEA \{European Medicines Agency\} (2005): "Scientific Discussion". Available at http://www.ema.europa.eu/ docs/en_GB/document_library/EPAR_ Scientific_Discussion/human/000154/ WC500058424.pdf

Erhardt, J. G.; Lim, S. S.; Bode, J. C. and Bode, C. (1997) : "A diet rich in fat and poor in dietary fiber increases the in vitro formation of reactive oxygen species in human feces". J. Nutr., 127: 706-709.

\section{FDA Drug Safety Communication} (2010) : Completed safety review of Xenical / Alli (Orlistat) and severe liver injury: http://www.fda.gov/Drugs/Drug Safety/PostmarketDrugSafety InformationforPatientsandProviders/ucm213038.htm. Page last updated 08/02/2010.

Food and Drug Administration \{FDA\} (2007) : The Diet Drug Orlistat (XENICAL, ALLI) and Gallstones. Available at http:/ /www.worstpills.org/public/page.cfm? op_id=71. 
Fukushima, S.; Wanibuchi, H. and Li, W. (2001) : "Inhibition by Ginseng of Colon Carcinogenesis in Rats". J Korean Med. Sci., 16: S75-80.

Garcia, S. B; Barros, L. T.; Turatti, A.; Martinello, F.; Modiano, P.; RibeiroSilva, A. and Uyemura, S. A. (2006) : "The anti-obesity agent Orlistat is associated to increase in colonic preneoplastic markers in rats treated with a chemical carcinogen". Cancer letters, 240 (2): 221224.

Hao, M.; Wang, W.; Zhao, Y.; Zhang, R. and Wang, H. (2011) : "Pharmacokinetics and tissue distribution of 25hydroxyprotopanaxadiol, an anti-cancer compound isolated from Panax ginseng, in athymic mice bearing xenografts of human pancreatic tumors". Eur. J. Drug Metab. Pharmacokinet., 35(3-4): 109-113.

Hoffmann La-Roche Inc (2008) : "Material Safety Data Sheet, Xenical (R) capsules $(120 \mathrm{gm})$. Available at http:// www.gene.com/gene/products/ information/msds/xenical/ MSDS_Xenical_ca120mg.pdf.

Iain, A. B.; John, K.; Peter, W. D. and Jeffrey, P. P. (2007): "Action of reactive oxygen species on colonic mucus secretions". Free Radical Biology and Medicine, 43 (5): 800-808.
Joyce, B. H. (1998) : "assessment of the efficacy and safety of Orlistat for longterm management of obesity". J. Nutr. Biochem., 9:516-521.

Kridel, S. J.; Axelrod, F,; Rozenkrantz, N. and Smith, J. W. (2004) : "Orlistat is a novel inhibitor of fatty acid synthase with antitumor activity". Cancer Res., 64 : 20702075.

Kubben, F. J.; Peeters-Haesevoets, A.; Engels, L. G.; Baeten, C.G.; Schutte, B.; Arends, J. W.; Stockbrügger, R. W. and Blijham, G. H. (1994): "Proliferating Cell Nuclear Antigen (PCNA): a new marker to study human colonic cell proliferation". Gut, 35(4): 530-535.

Lazic, T.; Wilkel, C.; Della-Torre, L.; Robinson-Bostom, L. and Fonder, M. (2011) : "Orlistat-induced bullous leukocytoclastic vasculitis". Journal of the American Academy of Dermatology, 64 (2) Sup plement 1: AB44.

Lee-Ping, P. (1997) : FDA Mathematical Statistician Memo. Ph.D. Available at web:http:/ / web.archive.org / 20061013145139/http:/ / www.fda.gov/ cder/foi/nda/99/020766a_xenical_statr_ P1.pdf. Now availale at: http:// web.archive.org/web/20061013145139/ http:/ / www.fda.gov/cder/foi/nda/99/ 020766a_xenical_statr_P1.pdf. Last ac- 
cessed March 27, 2008.

Li, M. and Cheung, B. M. (2009) : "Pharmacotherapy for obesity". Br. J. Clin. Pharmacol., 68(6): 804-810.

Li, W.; Wanibuchi, H.; Salim, E.; Wei, M.; Yamamoto, S.; Nishino, H. and Fukushima, S. (2000) : "Inhibition by Ginseng of 1,2 dimethylhydrazine induction of aberrant crypt foci in the rat colon". Nutr. Cancer, 36: 66-73.

Martínez-Lara, I.; González-Moles, M.; Ruiz-Avila, I.; Bravo, M.; Ramos, M. and Fernández-Martínez, J. (1996) : "Proliferating cell nuclear antigen (PCNA) as a marker of dysplasia in oral mucosa". Acta Stomatol. Belg., 93(1): 29-32.

Melia, A. T.; Koss-Twardy, S. G. and Zhi, J. (1996) : "The effect of Orlistat: an inhibitor of dietary fat absorption, on the absorption of vitamins $A$ and $E$ in healthy volunteers". J. Clin. Pharmacol., 36: 47-653.

Morin, B.; Jean-François, N.; Daniel, R.; Carine, B. and Jean-Luc, R. (2008) : "Effect of dietary fat-soluble vitamins $A$ and $\mathrm{E}$ and proanthocyanidin-rich extract from grape seeds on oxidative DNA damage in rats". Food and Chemical Toxicology, 46 (2): 787-796.

Motiwale, L.; Ingle, A. D. and Rao, K.
V. (2005) : "Mouse skin tumor promotion by sodium arsenate is associated with enhanced PCNA expression". Cancer Letters, 22.3(1): 27-35.

Murillo, G.; Nagpal, V.; Tiwari, N.; Benya, R. V. and Mehta, R. G. (2010): "Actions of vitamin $D$ are mediated by the TLR4 pathway in inflammation-induced colon cancer". Steroid. Biochem. Mol. Biol., 121(1-2): 403-407.

Narayan, S.; Zhaocheng, T.; Andra, F. and Oliver, A. (1995) : "Inhibition of progression of aberrant crypt foci and colon tumor development by vitamin $\mathrm{E}$ and ?carotene in rats on a high-risk diet". Cancer Letters, 91 (1): 125-132.

Nishioko, T.; Hafkamp, A. M.; Havinga, R.; Lierop, P. P.; Velvis, $H$. and Verkade, H. J. (2003) : "Orlistat treatment increases fecal bilirubin excretion and decreases plasma bilirubin concentration in hyperbilirubinemic gunn rats". J. Pediatr., 143: 327-334.

Peter, G. and Keith, D. L. (2004) : "Hepatotoxicity of drugs used for treatment of obesity and its comorbidities". Seminars in Liver Disease, 24 (4): 389- 398.

Piva-Demarzo, M. M. and Garcia, S. B. (2004) : "Exhaustive physical exercise increases the number of colonic preneo- 
plastic lesions in untrained rats treated with a chemical carcinogen". Cancer Letters, 216: 31-34.

Prescription Drug Reference (PDR\} (2006) : "Guide to drug interactions, side effects and indications". Thomson PDR, Montvale, N.J.

Radtke, F. and Clevers, H. (2005) : "Self-renewal and cancer of the gut: two sides of a coin". Science, 307 (5717): 19041909.

Saw, C. L.; Wu, Q. and Kong, A. N. (2010) : "Anti-cancer and potential chemopreventive actions of ginseng by activating Nrf2 (NFE2L2) anti-oxidative stress/ anti-inflammatory pathways". Chin. Med., 27 (5): 37.

Sjostrom, L.; Rissanen, A.; Andersen, T.; Boldrin, M.; Golay, A.; Koppeschaar, H. and Krempf, M. (1998): "Randomized placebo-controlled trial of Orlistat for weight loss and prevention of weight regain in obese patients". Lancet, $352: 167-$ 173.

Takayama, T.; Katsuki, S.; Takahashi, Y.; Ohi, M.; Nojiri, S.; Sakamaki, S.; Kato, J;; Kogawa, K.; Miyake, H. and Niitsu, Y.
(1998) : "Aberrant crypt foci of the colon as precursors of adenoma and cancer". N. Engl. J. Med., 339 (18): 1277-1284.

Thornton, W. H, and MacDonald, R. S. (1997): "Dietary fat quantity and composition induce changes in proliferation and membrane lipids in rat colon cells". Ann. Nutr. Metab, 41: 260-268.

Toh, D. F; Patel, D. N.; Chan, E. C.; Teo, A.; Neo, S. Y. and Koh, H. L. (2011) : "Anti-proliferative effects of raw and steamed extracts of Panax notoginseng and its ginsenoside constituents on human liver cancer cells". Chin. Med., 24(6): 4 [Epub ahead of print].

Umemura, $\mathrm{T}$; Tetsuya, I.; Akihiro, M. and Kendo, K. (2006) : "Severe hepatic injury caused by Orlistat". The American Journal of Medicine, 119 (8): e7.

Victor, R. P. and Ronald, R. W. (2006): "The encyclopedia of vitamin E". p: 787, CABI publishing.

Yamashita, N.; Minamoto, T.; Onda, M. and Esumi, H. (1994) : "Increased cell proliferation of azoxymethane-induced aberrant crypt foci of rat colon". Jbn. J. Cancer Res., 85: 692-698. 


\title{
دراسة التكاثر الخلوبي القولوني الناني عن التسهمم الهزمسن بعتار الإوليستات

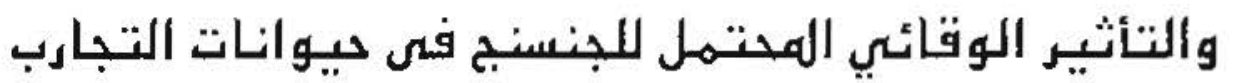
التشتركون نى البحث

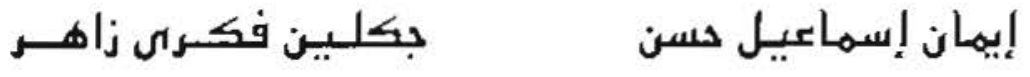 \\ غـادة عطية اسـحق \\ هن تسمى الطب الشرعي والسموم رالهسترلوجى* - كلية الطب - جامعة الميبا
}

يستخدم عنار الاورليستات كمضاد للسمنة وشو متاح كعتار يكن استخدامه لفترات طويلة بدون اذن الطبيب فى كثير من الدول المتقدمة كا يؤدى الى حدوث تسمم مزمن به. تمت هذه الدراسة لتوضيح تأثير عقار الاورليستات على التكاثثر الحلوي القولوني و دوره فى تكوين البور

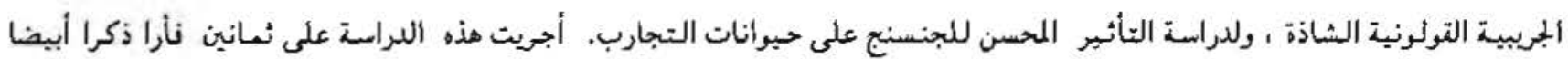
بالفا تسمت إلى 8 مجموعات: المجعوعة الأرلى (الضابطة) غذيت على غذانها المعتاد ، المجموعة الثانبة (الجنسنج) أضيف 1\% جنسنج أحمر الى غذايها ، المجموعة الثالثة (التغذية عالبة الدهون) أضميف الى غذانها \% 10 زيت ذره ، المجموعة الرابعة (الاورليستات) أعطيت العقار بجرعة 125 مبهم / كجم / اليوم عن طريق الفم ، ألجموعة الخامسة اعطبت الاررليستات + التغذية عالية الدهون ، المجموعة السادسة أعطيت التغذية عالية الدهون + الجنسنج ، المجموعة السابعة أعطيت الابرلبستات + الجنسنج ، وأخبرا المجموعة الثامنة اعطيت الاررليستات + التغذية عالبة الدهون + البنسنج. وبعد 16 أسبوعا تم ذبح الفئران وصبغ القولون لكل منهم مناعبا باستخدام المولد المضاد للتكاثر المنلوي النوري كدلالة للتكاثر المنلوي و كمنشر لزيادة القابلية لسرطان الجهاز الهضمي. وتد أظهرت النتانج أن كل من الاررليستات أو التغذية عالية الدهون أو كليهـا تسبب نى زيادة اللصن المناعي للالالة المولد المضاد اللتكاثر التلوي النوري مما أدى ألى زبادة ذات دلالة احصانية لمؤشر اللصق لهذه العلامة مقارنة بالمجموعة الضابطة. وقد سبب الجنسنج مضافا الىى الاروليستئات أو التغذبة عالية الدهون أر كلبهـا معا نقصا زو دلالة

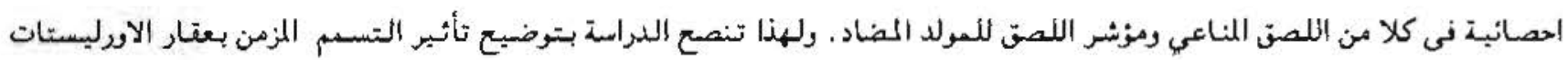

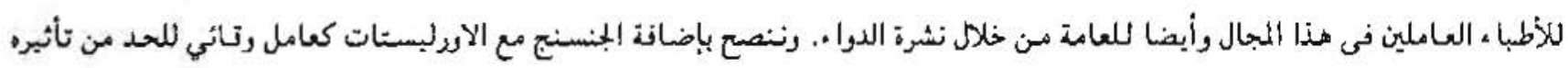
ألتكاثري على الغشاء ألمخاطي للقولون. 